\title{
Skills obsolescence: causes and cures
}

\author{
Citation for published version (APA):
}

van Loo, J. B., \& de Steur, M. J. (2001). Skills obsolescence: causes and cures. Researchcentrum voor Onderwijs en Arbeidsmarkt, Faculteit der Economische Wetenschappen. ROA Research Memoranda No. 3E https://doi.org/10.26481/umaror.200103E

Document status and date:

Published: 01/01/2001

DOI:

10.26481/umaror.200103E

Document Version:

Publisher's PDF, also known as Version of record

\section{Please check the document version of this publication:}

- A submitted manuscript is the version of the article upon submission and before peer-review. There can be important differences between the submitted version and the official published version of record.

People interested in the research are advised to contact the author for the final version of the publication, or visit the DOI to the publisher's website.

- The final author version and the galley proof are versions of the publication after peer review.

- The final published version features the final layout of the paper including the volume, issue and page numbers.

Link to publication

\footnotetext{
General rights rights.

- You may freely distribute the URL identifying the publication in the public portal. please follow below link for the End User Agreement:

www.umlib.nl/taverne-license

Take down policy

If you believe that this document breaches copyright please contact us at:

repository@maastrichtuniversity.nl

providing details and we will investigate your claim.
}

Copyright and moral rights for the publications made accessible in the public portal are retained by the authors and/or other copyright owners and it is a condition of accessing publications that users recognise and abide by the legal requirements associated with these

- Users may download and print one copy of any publication from the public portal for the purpose of private study or research.

- You may not further distribute the material or use it for any profit-making activity or commercial gain

If the publication is distributed under the terms of Article $25 \mathrm{fa}$ of the Dutch Copyright Act, indicated by the "Taverne" license above, 
Skills Obsolescence: Causes and Cures

\author{
ROA-RM-2001/3E \\ Jasper van Loo, Andries de Grip and Margot de Steur
}

Research Centre for Education and the Labour Market

Faculty of Economics and Business Administration Maastricht University

Maastricht, April 2001 
ISBN 90-5321-309-0

Sec01.017.doc 


\section{Contents}

Pages

Abstract

1 Introduction 1

2 Skills obsolescence, types, causes and remedies 1

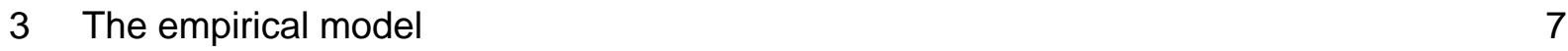

4 Wear 8

5 Job-specific skills obsolescence 10

6 Skills obsolescence: by market developments or company-specific 12

7 Conclusions 15

$\begin{array}{ll}\text { References } & 16\end{array}$ 



\begin{abstract}
Until now there has been surprisingly little research on the causes of and the remedies for skills obsolescence. This study tries to fill that gap to some extent by analysing the relation between risk factors and skills obsolescence. Moreover, the role remedies play to counter skills obsolescence is analysed. Four empirical analyses that relate skills obsolescence to risk factors and remedies are presented. We find that most risk factors identified in the literature can be validated empirically. The remedies for skills obsolescence are not effective in all situations: the results show that there is considerable variation in the effectiveness of the remedies across different types of skills obsolescence. Although current available data does not allow a comprehensive analysis, which also takes account of relations between the various types of skills obsolescence, the results obtained are plausible and offer a starting point for further research.
\end{abstract}




\section{Introduction}

Various developments in society increase the role that human capital plays in competitiveness and economic growth (see e.g. OECD, 1996). In addition to providing opportunities for workers, these developments may also imply risks. Employees with outdated skills may run a high risk of becoming unemployed (see Johnston, 1994). Training workers is often referred to as an instrument that can lower this risk by expanding or refreshing skills (see e.g. Bishop, 1997). In addition, recently the employability of employees is increasingly recognised as a second unemployment-risk-countering instrument.

The process of depreciation of skills is called skills obsolescence. Workers are exposed to different kinds and intensities of risks that cause skill obsolescence. There is surprisingly little research on the causes of and the remedies for skills obsolescence. This paper tries to fill that gap. Two questions will be addressed. The first deals with the relation between skills obsolescence and the various risk factors employees face. The second question we try to answer in this paper is whether additional training or workers' employability is an antidote for skills obsolescence.

Skills obsolescence can manifest itself in a variety of ways. Since the possible risk factors associated with them differ between these types, we adopt an approach where the types of skills obsolescence are distinguished and analysed separately. This has the advantage that the causes and the remedies for skills obsolescence can be investigated in a way that takes account of the differences between the various types of skills obsolescence. A drawback of this approach is that it ignores possible relations between the different types of skills obsolescence. Although we are aware of these possible relations, it is not possible to perform an integrated analysis due to data limitations. Therefore, we have to analyse different types of skills obsolescence in a partial way. This approach should be seen as a starting point for further research in this field.

The set-up of the rest of the paper is as follows. In section 2, we first provide definitions of the various types of skills obsolescence, the risk factors and the possible remedies we distinguish between in the paper. At the end of this section, we also give a short description of the data we used for the empirical part of this paper. We present the empirical model we apply in this paper in section 3. The rest of the paper is devoted to empirical analyses for each type of skills obsolescence. In section 4 , we deal with wear. In section 5, job-specific skills obsolescence is analysed. Section 6 is devolved to analyses of skills obsolescence by market developments and company-specific skills obsolescence. The final section contains our main conclusions.

\section{Skills obsolescence, types, causes and remedies}

Skills obsolescence occurs when skills become less valuable in the production process of a firm. Skills can be regarded as the human capital counterpart of physical inputs in the production process. In principle there are two main types of skills obsolescence we can distinguish: Analogously to economic theory regarding the depreciation of physical capital 
we can roughly divide between technical and economic skills obsolescence (see Neumann \& Weiss, 1995). Most other empirical studies studies have, however, been primarily concerned with technical skills obsolescence (see e.g. McDowell, 1982).

Technical skills obsolescence is the process of skills depreciation due to changes in workers themselves. A typical example of skills obsolescence is the depreciation of manual skills or physical strength due to ageing. Technical skills obsolescence is illustrated in figure 1a. Due to ageing, a worker may loose some of manual skills, which is shown as the movement from $\mathrm{q} 1$ to $\mathrm{q} 2$. The skill value decreases as a result, as the TSO-arrow illustrates.

In addition, the productive value of a skill may decrease due to changes in production technology. Technological improvements, such as e.g. the introduction of computer technology may change the optimal input mix for firms. This type of skills obsolescence is called economic skills obsolescence. A typical example of such an improvement is the introduction of personal computers in an office environment. Such an innovation will decrease the value of basic typing skills. At the same time, computer skills will become more valuable. Figure $1 \mathrm{~b}$ illustrates the economic depreciation of typing skills. The upward sloping line SV1 expresses the relationship between skill quality and skill value before the introduction of computers. It is positively sloped since better skill quality presumably adds more to production. When computers are introduced, the value of typing skills shifts down to SV2. As a result, a worker with a typing skill quality q will add less to production. The ESOarrow shows the magnitude of this productive value loss.

Figure 1

Technical and economic skills obsolescence

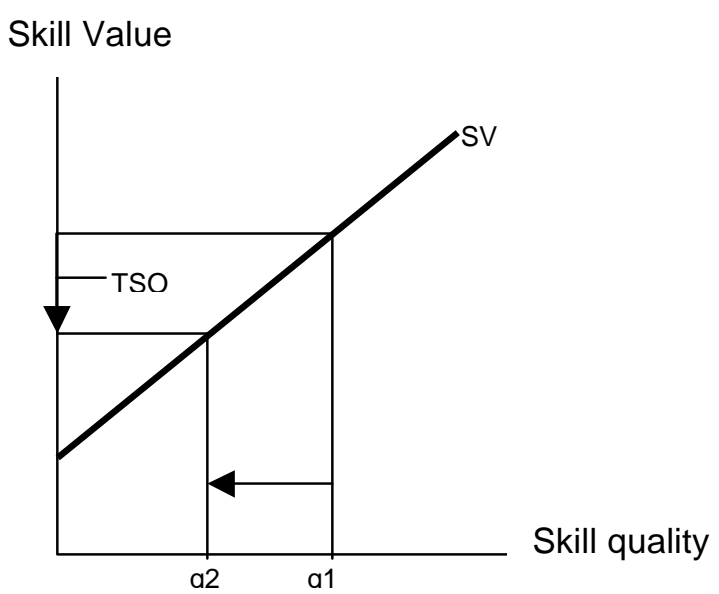

1a: Technical skills obsolescence

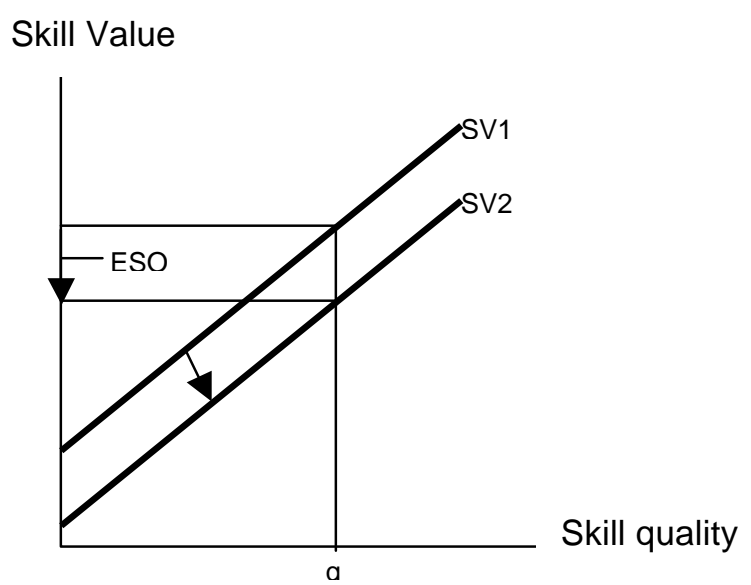

1b: Economic skills obsolescence

Skills obsolescence can manifest itself in a variety of ways. Table 1 lists the five different types of skills obsolescence we distinguish between in this paper (see De Grip et al., 1997). 
Table 1

Types of skills obsolescence

Type of skills obsolescence

Depreciation of human capital by:

Technical skills obsolescence

Wear

Natural ageing process, illness, or injury

Atrophy

No or insufficient use of skills

Economic skills obsolescence

Job-specific skills obsolescence

New skill requirements for the job due to developments in society

Skills obsolescence by market developments

Shrinking employment in occupation or economic sector

Company-specific skills obsolescence

External mobility

The first two types of skills obsolescence distinguished in table 1 are technical in nature. Both wear and atrophy imply a depreciation of human capital, which originates from changes in workers themselves. Wear refers to the natural ageing process, injury or illness. Atrophy occurs when skills are temporarily not used, which may cause skill depreciation. ${ }^{1}$ There are three types of economic skills obsolescence. First of all, job-specific skills obsolescence arises when job-requirements change. Secondly, skills may lose their productive value when employment shrinks in an occupation or a sector of industry, forcing workers to change jobs. This is called skills obsolescence by market developments. Finally, company-specific skills obsolescence occurs when workers have change jobs due to adverse economic conditions in the firm they work in. This reallocation process may cause firm-specific skills to depreciate.

\section{Skills obsolescence and risk factors}

Different types of skills obsolescence are caused by different risk factors. In the case of wear, taxing labour conditions are important risk factors. In addition to causing wear in some workers, taxing work conditions can cause adverse productivity effects for firms, such as reduced productivity and high hiring, training and firing costs. These adverse firm effects will, however, not be discussed. Wear will only be analysed from a worker's point of view.

1. To be able to measure this type of skills obsolescence in a meaningful manner, individual workers' competences should be measured at different points in time. Moreover, data which include questions about the usage of some skills in the work situation or someplace else should be available. Since, in current data sources, this information is not available, atrophy cannot be related to the incidence of risk factors. When, in the future, data sources with take competences as their main viewpoint (see e.g. in the United Kingdom Green et al., 1997) become available, measuring atrophy and relating it to risk factors might become possible. 
Job-specific skills obsolescence occurs when job-content changes due to changes in society. When these changes are drastic, employers may start demanding other qualifications in their recruitment process. In addition to changes in the required type of qualifications, the level of the qualifications employers demand may also increase. On a macroeconomic level, these 'upgrading' tendencies manifest themselves through a changing structure of occupations and shifts in the educational level within occupations. In the first case the share of elementary occupations decreases while employment in higher occupations expands; in the second case, upgrading manifests itself through increases in the occupational level in some occupations (see De Grip \& Hoevenberg, 1996).

Job-specific skills obsolescence is closely related to various developments in society. Pillay (1998) and Watkins \& Marsick (1993) point out that organisational developments such as reorganisations and changing management systems can have a dramatic influence on jobcontent and may therefore increase the risk of job-specific skills obsolescence. Organisational developments are often initiated by changes in the production process. Classic intensely specialised mass production is increasingly replaced by a new mode of production that takes the tailor-made product as its main focus. This requires flexible organisations.

In addition, new technologies often require new or other skills within the same job (see Watkins \& Marsick, 1993). A clear example of this is the increasing usage of information technology (IT). Research shows (see e.g. Wolff, Forthcoming in 1999) that this IT-trend causes changes in skills requirements. Another important tendency in society that reshapes skill requirements is the increase in international competition (see e.g. Watkins \& Marsick, 1993) caused by the entry of new firms on national markets or increased competition on foreign markets. Finally, demographic developments can play an important role (see Bélanger \& Falgás, 1997). Older employees run a higher risk of job-specific skills obsolescence since they received their initial education earlier than their younger colleagues. In addition, virtually all studies on training participation have shown that training intensity decreases with age (see, for an overview Groot, 1998), making the risk of skills obsolescence for older workers even more acute.

Skills obsolescence by market developments occurs when employment in some occupation or sector of industry shrinks, forcing workers to move to another occupation or sector of industry. In this process, they may loose part of their human capital. In addition, workers may be forced to change firms, leading to company-specific skills obsolescence. Both types of mobility are involuntary and may cause skills obsolescence. This obsolescence is more problematic when skills are highly occupation-, industry- or company-specific. Risk factors for this type of skills obsolescence are labour demand changes by sector of industry, occupation, and/or type of educational background.

When workers have to change firms within a sector of industry, they may loose some of their (firm-specific) skills in the process. In that case company-specific skills obsolescence takes place (see De Grip et al., 1997). In this case, the risk factor is obvious: Mobility between firms contributes to the risk of this type of skills obsolescence. 
Three concepts are relevant in countering skills obsolescence. Firstly, mobility enables employees to stay employable by expanding their experience base (see Hyatt, 1995). In addition, training is considered an instrument to deal with skills obsolescence since it allows workers to update their skills. (see e.g. Bishop, 1997). Finally, the 'functional flexibility', or the flexibility of employees to perform tasks that are not part of their job, can counter skills obsolescence by making workers more familiar with continuing change. (see Rajan, 1996 and Thijssen, 1997).

Table 2

Remedies for skills obsolescence

Indicator

Operationalisation

Willingness to be mobile across jobs

Search behaviour on the workers' initiative in the last 12 months prior to survey

Capacity to be mobile across jobs

Tenure in current job vs. duration on the labour market, corrected for age

Willingness to participate in training

The extent to which workers participate in training, determined by the number of courses (not necesarily completed succesfully)

Capacity to participate in training

The total amount of time a worker has spent in education, encompassing initial education as well as further training

Willingness to be functionally flexible

Willingness to carry out tasks which are not part of the current job

Capacity to be functionally flexible

Frequency of doing tasks which are not part of the current job in the past

These three concepts will be operationalised using two dimensions. Firstly, the willingness to be mobile across jobs, to participate in training and to be functionally flexible is considered. The second dimension concerns the capacity to perform these actions. This dimension is considered separately since with a higher capacity to learn, to be mobile or to be functionally flexible, the willingness to do so probably becomes more effective. Combining these three two-dimensional concepts yield six possible remedies for skills obsolescence. In table 2 these potential remedies are defined.

The willingness to be mobile across jobs concerns the willingness to be internally as well as externally mobile. This characteristic enhances the probability of keeping work, since it allows workers to develop their human capital by endowing them with a wide range of experience. It also prevents excess 'concentration of experience' (see Thijssen, 1987). The willingness to be mobile across jobs is measured by workers intentions to change jobs. Whenever an employee is motivated to change jobs on a regular basis, the willingness to be 
mobile is high. Obviously, workers themselves should induce this search behaviour. Search behaviour due to external factors (e.g. fear of losing ones job) should not be taken into account when determining someone's willingness to be mobile, since in that case the desired mobility does not indicate employability. Therefore only search behaviour initiated by workers themselves is considered when the willingness to be mobile is determined.

The capacity to be mobile across jobs is another important factor determining the extent to which a worker is able to counter skills obsolescence. If a worker is willing to be mobile across jobs, but lacks the capacity to do so, this characteristic will be of no or little value. The capacity to be mobile across jobs is determined by three factors. The first two factors are tenure in the current job vs labour market tenure. Workers with high tenures and long careers are expected to be less able to be mobile across jobs. Finally, age is important: an older worker with all tenure in a single job is considered less capable of being mobile across jobs than a younger worker in a similar situation. The three elements (total tenure on the labour market, job tenure and age) together are used to determine someone's capacity to be mobile across jobs.

The willingness to participate in training is defined as the willingness of employees to invest time and/or money in the development of their human capital. As stated earlier, being involved in training activities is often seen as a key remedy for skills obsolescence. The willingness to participate in training is influenced by a number of factors, such as previous experience with training, the assessment of one's own capacities, and the willingness to finance one's personal training. Using variables like these would be the preferred way to measure the willingness to participate in training, but they are not available in the dataset. Therefore, the average yearly number of training courses is used. Whether these courses have been successfully completed is not relevant for the willingness to participate in training; this variable therefore includes all training courses.

The capacity to participate in training influences the effectiveness of the willingness to be involved in training, since workers with higher capacities are likely to gain more from a high willingness to participate in training. The ability to acquire new skills is determined by the quality of learning skills and by the knowledge already available. To estimate one's capacity to participate in training, the total duration of education and training is used. This includes both the duration of a worker's initial education as well as the total duration of successfully completed training courses. Whether a training course has been successfully completed is important for determining the capacity to participate in training: A worker with more successfully completed training courses obviously has better learning skills and is therefore more able to participate in training than a worker with less success in training.

The willingness to be functionally flexible is the willingness to carry out tasks that are not part of the current job. This 'qualitative' flexibility may counter skills obsolescence since it gives employees a wide range of different experiences. In addition, workers' willingness to be flexible in terms of working hours plays an important role. However, this 'numerical' flexibility is constrained by the type of contract a worker has. Employees with flexible contracts are probably more likely to be willing to work irregular hours or overtime. Therefore, the indicator for the willingness to be functionally flexible only includes qualitative flexibility. 
The capacity to be functionally flexible is important since the willingness to do so is more effective when workers are better able to perform different tasks. For example, workers with some kind of disability may be willing to be functionally flexible, but are not able to do so, making them less employable then their better able colleagues. The capacity to be functionally flexible is determined by considering the frequency of performing tasks that are not part of one's job. Workers who have been involved in these tasks a lot, are expected to have a higher capacity to be functionally flexible than those who indicate that they have performed tasks not part of their job very infrequently.

\section{Data used}

The empirical analyses in this paper based on the Netherlands labour-supply-survey, a biannual survey of individuals carried out by the Organisation for Strategic Labour Market Research (OSA). In this panel survey, individuals are questioned about their current labour market position, their educational background, additional training, recent changes in labour market status. Opinions about policy measures, general developments in society and some aspects of employability are also included.

In this article, we use the 1994 and 1996 labour-supply-surveys. The survey has 4538 cases in 1994; in 19964563 cases are available for analysis. A number of pre-selections were made. Firstly, only persons between the age of 15 and 65 were considered. In addition, the self-employed were left out of the analyses. Since the separate analyses in this paper require different variables and different groups of workers, the pre-selections are different for each type of skills obsolescence analysed. This implies that the number of cases available differs across analyses. As an example, fewer cases are available in the parts where both survey years 1994 and 1996 are used, since there only people that responded in both years were considered.

\section{The empirical model}

For the empirical analyses of skills obsolescence we use a binomial logit specification. In such a model, the dependent variable takes only two values, zero or one (see e.g. Maddala, 1983).

The data we use are individual observations and for each individual the dependent binomial variable takes value one if he suffers from a specific kind of skills obsolescence and is zero if this is not the case:

$S O_{i}=1:$ Respondent suffers from type $\mathrm{i}$ of skills obsolescence

$S O_{i}=0:$ Respondent is not confronted with type i of skills obsolescence

The $\mathrm{SO}_{i}$ variable is different each type of skills obsolescence. In each empirical analysis, it is related to three kinds of explanatory variables. Firstly, for each type of skills obsolescence 
i a number of risk factors $R F_{i}$ are considered. These are expected to have a positive effect on the probability that an individual worker suffers from skills obsolescence. The remedies for skills obsolescence $\left(R E M_{i}\right)$ are expected to have a negative influence on $S_{i}$, which implies that they decrease the probability of skills obsolescence. Finally, a number of other risk determining factors $O R F_{i}$ are included. Some of these are risk-increasing, others are risk-decreasing.

To summarise, the models that will be estimated have the following econometric specification (expected signs beneath coefficients):

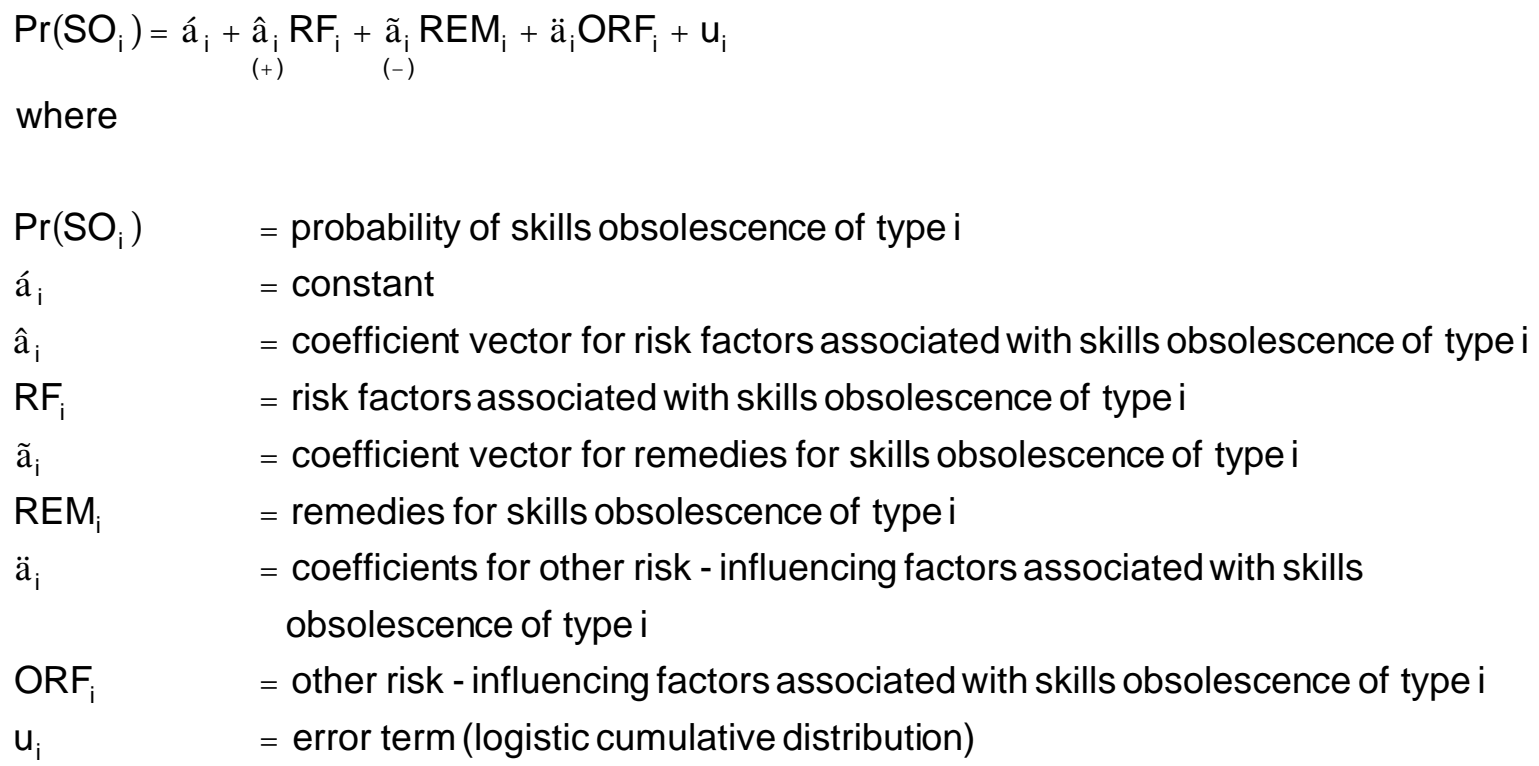

\section{Wear}

Ideally, wear should be measured by the changes in workers' physical and mental capacities over time. This is very difficult with datasets currently available. In the dataset we use, it is, however, possible to measure some of the possible consequences of wear. Wear can e.g. cause work disability, mobility to less taxing jobs (see Chelius, 1974) and/or increased sick leave. Two of these potential measures of wear are, however, not very suited. Firstly, an important disadvantage of using workers' disability as an indicator for wear is that working conditions are not the only cause for this. Disability can also be caused by an unfortunate accident on- or off-the-job. In this case, it is very unlikely that work conditions play an important role explaining workers' wear. A similar argument holds for worker mobility. Since mobility can have many causes (e.g. improved career perspectives, personal circumstances or even dismissal), using it as an indicator for the effects of wear would imply serious measurement errors. Given the potential disadvantages of using disability or job mobility as an indicator of wear, we use long-time job related sick leave as an indicator for wear instead. In terms of the model explained before, respondents who suffered from a work-related 
illness for an extended period of time are assigned a one $\left(S_{i}=1\right)$, while the others are considered the reference category $\left(\mathrm{SO}_{i}=0\right)$.

We relate long-time job related sick leave to three types of variables. Firstly, we include risk factors, which are job characteristics that give information about the severity of taxing work conditions. Examples of these characteristics are the level of stress or physical strain a worker encounters in his job. ${ }^{2}$ Secondly, activities that reduce (the influence of) wear (remedies), such as participating in training courses that teach employees to arrange their work to minimise the influence of taxing labour conditions, can be relevant and were initially included. Finally, some other risk-influencing factors are included.

\section{Results}

In table 3 below, the results of the binomial logit estimation for wear are presented. The risk factors that are expected to have a positive influence on the risk of wear are working conditions. From a correlation analysis of the available working conditions in the dataset, it became clear that a number of these working conditions are highly correlated. In order to avoid estimation problems due to multicollinearity, we excluded those risk factors that showed correlation coefficients of over 0.5 with other risk factors. The analysis reveals that both physically and mentally taxing labour conditions have a positive effect on the probability of wear.

The variables that represent possible remedies for wear are expected to decrease the probability of wear and were all included in the initial estimation. These remedies were, however in general insignificant and were therefore left out of the model. The only exception is the 'willingness to be mobile across jobs', but this variable has a positive sign, implying an increase in the probability of wear. Probably, people that indicate that they want to change jobs, do this also because of a general dissatisfaction with their current job.

Finally, the analysis contains two other risk-influencing factors. Age has an expected positive effect on the probability of wear, which is probably due to the fact that older workers are more susceptible to wear since they have often been longer exposed to taxing working conditions compared to their younger colleagues. Occupational level is included in the model since it is expected that workers in higher occupations, who have usually received a higher level of education, are better able to deal with taxing work conditions. The analysis reveals that occupational level has a significant negative effect, implying that workers in higher occupations indeed run a lower risk of wear.

2. The job characteristics that are considered are: 1 . Stench, noise, draft, temperatures; 2 . Work with dangerous substances; 3 . Dangerous work conditions; 4 . Physically taxing work conditions; 5. Mentally taxing work conditions; 6 . Conveyor belt; 7 . Repetition of same, simple tasks; 8 . Work in shifts; 9. Autonomy over working hours; 10 . Irregular work hours; 11 . Work on Saturday; 12 . Work on Sunday; Work outside the occupation; 14. Working with people; 15. Flexible yearly work schedule and 16 . Flexible weekly job schedule. 
Table 3

Workers' wear explained using a binomial logit model, standard errors in parentheses

Variable

Coefficient

Risk factors: job conditions

Stench, noise, draft, temperatures

0.5745

0.5674

$(0.1976)^{\star \star}$

Mentally taxing conditions

$0.6411(0.2006)^{\star *}$

Repetition of same simple tasks

Remedies

Willingness to be mobile across jobs

$0.7573(0.2667)^{\star \star}$

Other risk influencing factors

Age

$0.0218 \quad(0.0092)^{\star *}$

Occupational level

$-0.1310$

$(0.0542)^{* *}$

Constant

$-4.3902$

(0.4657)

-2 Log Likelihood $=946.91$

$\mathrm{n}=2964$

${ }^{\star *}=$ significant at a $5 \%$ level of significance

\section{Job-specific skills obsolescence}

Job-specific skills obsolescence could best be measured by comparing both the skills requirements and the available skills workers have in a certain job, at a number of different points in time. This is, however, not possible using currently available data. Therefore, a proxy for job-specific skills obsolescence is used. People who indicate that their qualifications have depreciated due to changes in their job are considered to suffer from jobspecific skills obsolescence $\left(S O_{i}=1\right)$, while people that do not are assigned to the reference category $\left(S_{i}=0\right)$.

The variables we use to measure the intensity of the different developments in society are mostly not available on the individual level. Therefore, other datasources such as the Labour Force Survey were used and the resulting variables were linked to the dataset using industry or occupational codes.

Organisational changes were measured using the percentage of companies in a sector of industry that has experienced reorganisations. Technological developments are measured by the use of information technology (IT) in 127 different occupations. It is expected that workers, who make extensive use of information technology in their daily work activities, are the most vulnerable to technological changes. In addition, it may be expected that workers who use IT intensively also use the more advanced possibilities, which implies that changes in IT may be quite drastic for these workers. Developments in international competition are 
measured in two distinct ways. Firstly, an individual dummy variable that indicates whether a worker is employed in a firm that is involved in imports or exports is available. In addition, a variable that expresses the 'openness' of the sector of industry a worker is employed in is linked to the individual cases (see De Grip et al, 1999). Finally, two variables that express demographic developments are included as risk factors. Firstly, the age of the worker is included, since it is expected that older workers run a higher risk of job-specific skills obsolescence due to the fact that they received their initial education earlier and therefore are more likely to posses outdated qualifications. Secondly, a variable that is defined as the distance between a worker's age and the average age in the occupation is taken into account. Workers that are relatively old compared to their younger colleagues are expected to have a higher probability of encountering job-specific skills obsolescence.

In the first estimation we performed, all risk factors described were included. In addition, the possible remedies for skills obsolescence (see table 2) were included in the analysis. No other risk-influencing factors were included.

Results

The way in which the risk factors influence the occurrence of job-specific skills obsolescence and the effects of the remedies for skills obsolescence are presented in table 4. A key result from the analysis is that job-specific skills obsolescence is fostered by the degree of technological and organisational developments. Demographic tendencies also matter: a worker with a larger age-gap runs a higher risk of job-specific skills obsolescence. Developments in international competition were initially included in the estimation, but have no

Table 4

Job-specific skills obsolescence explained using a binomial logit model, standard errors in parentheses

Variable

coefficient

Risk factors: developments

Use of information technology by occupation

Organizational developments by sector of industry

Demographic developments: age gap

$0.0141(0.0042)^{\star \star}$

$0.0152(0.0086)^{*}$

$0.0550(0.0140)^{\star *}$

Remedies

Willingness to participate in training

$-1.7704(0.8265)^{* *}$

Constant

-2 log likelihood $=436.34$

$\mathrm{n}=827$

${ }^{*}$ = significant at a $10 \%$ level of significance, ${ }^{* *}=$ significant at a $5 \%$ level of significance 
significant effect on the risk of job-specific skills obsolescence. This might be due to the fact that the data that were used for this are probably very imprecise proxies for the exposure to economic developments we want to measure. We therefore decided to exclude this variable from the estimation.

All remedies for skills obsolescence were included in the first estimation. Of these variables, however, only the willingness to participate in training courses decreases the probability of job-specific skills obsolescence. This implies that taking post-initial training courses is an important remedy for countering the effects of the different effects that take place in society. The other, insignificant remedy-variables were excluded from the model.

\section{Skills obsolescence: by market developments or company-specific}

To be able to measure skills obsolescence due to market developments or interfirm mobility, a stepwise approach has to be adopted. As a starting point, those people that were employed in the base year (1994) are considered. Skills obsolescence, either due to market developments or company specific can manifest itself in two distinct ways:

- Some workers may loose their jobs and flow from employment to unemployment or non participation, due to skills obsolescence by market developments;

- Another group of workers may suffer from skills obsolescence, but they do not loose their current job. In this case, skills obsolescence is caused by changes in occupation, sector of industry or the firm. Therefore, both skills obsolescence by market developments or company-specific skills obsolescence may occur here.

Measuring the first manifestation of skills obsolescence is relatively easy, since it only requires that flows from employment to unemployment and non-participation be measured. To measure the second manifestation of skills obsolescence is more complicated. Ideally, the changes in availability and quality of competences should be considered. This is an impossible task using databases currently available. Therefore, the use of a proxy is required. This proxy is constructed as follows: At two points in time, employees are asked to estimate the extent to which their qualifications are suited for their current job. These answers are ranked according to the degree of suitability and compared between the two survey moments. If there is a large decrease in the score, this implies that the qualifications have become less suited for the job an employee currently has. If this occurs, skills obsolescence, due to either market developments or firm changes, is said to have occurred $\left(S O_{i}=1\right)$. The two manifestations of skills obsolescence are estimated using seperate logit estimations ('nested' logit, see Maddala, 1983).

In the first analysis, where the probability of becoming either unemployed or nonparticipating is considered, both variables at the individual as well as the macro-level are utilised. It is expected that the risk of unemployment or non-participation is positively related to shrinking employment in the sector of industry one works in, the occupation one has and/or the type of educational background. In addition, the variables that are considered 
remedies for skills obsolescence, which are listed in table 2, are included in the initial estimations.

If there is skills obsolescence due to market developments that do not cause labour market outflow or skills obsolesence due to firm changes, this is likely to be related to changes in the situation a worker is in. There are three possible changes at the individual level we are able to distinguish between:

- Changes in the sector of industry one works in;

- Changes of the occupation one has;

- Changes of the firm one works in: interfirm mobility.

Another risk-influencing factor are flexible contracts. Flexible contracts are expected to increase the risk of unemployment or non-participation and were therefore included as a correction variable.

Results

The results of the first analysis are presented in table 5. The dependent variable indicates whether a worker has become unemployed or non-participating during the 1994-1996 time period $\left(S O_{i}=1\right)$. As explanatory risk variables, macro-developments in sectors of industry, occupations, and types of education were included. Changes in labour market demand are for the greater part measured by demand developments for types of educational backgrounds. The other demand dimensions are merely correction variables. For instance, when workers are faced with the risk of unemployment due to adverse demand developments in their type of educational background, this does not necessarily mean that they will loose their jobs. If the prospects of the occupation one has and/or the sector one is employed in are good, the position on the labour market might actually be quite secure.

From the initial analysis it became clear that only changes in the demand for types of education are significantly and positively related to the risk of becoming unemployed or nonparticipating. The developments by sector of industry or occupation had no significant effects. Therefore, we excluded these variables from the results shown in table 5 .

Furthermore, the initial analysis revealed that two of the six remedies for skills obsolescence listed in table 2 are statistically significant and have expected signs. The remaining four were left out of the analysis shown here. It is worth noting that the significant remedies both measure willingness to take certain actions. The capacity to do so seems to be less important. The analysis also reveals that workers with flexible labour contracts are more likely to become unemployed or non-participating compared to those who enjoy more stable employment relationships.

The results for the workers who do not become unemployed or non-participating but run a risk of skills obsolescence anyway are presented in table 6 . The changes a worker can be confronted with are defined using dummy variables that incorporate one or more changes and very unlikely changes (such as a change of economic sector without changing firms) are 
left out of the analysis. In addition, workers who suffer from job-specific skills obsolescence are not included, since this type of skills obsolescence has been dealt with earlier in this paper already. The data show that it is very unlikely that leaving this latter group of workers out of the analysis will change the results. Workers who suffer from job-specific skills obsolescence rarely change firms, occupations or economic sectors, which implies that this type of skills obsolescence generally does not coincide with skills obsolescence by market developments or company-specific skills obsolescence.

Table 5

Skills obsolescence (risk of unemployment or non-participation) by market developments explained using a binomial logit model, standard errors in parentheses

Variable coefficient

Risk factors: demand developments

Demand developments by type of education

$0.4703(0.2133)^{\star *}$

Remedies

Willingness to participate in training

Willingness to be functionally flexible

$-1.4514(0.6606)^{\star *}$

$-0.6201(0.1971)^{* *}$

Other risk influencing factors

Flexible contract

$1.0505(0.2547)^{* *}$

Constant

$-2.5497 \quad(0.2306)$

-2 log likelihood $=820.43$

$n=1808$

${ }^{* *}=$ significant at a $5 \%$ level of significance

The initial estimates included all possible change variables. A number of those variables, however, proved to be insignificant. Three of the change variables are significant and remain in the model. One can observe that of these three variables, changing occupation, sector of industry and firm at the same time has the highest positive effect on the probability that there is a substantial decrease in the suitability of the qualifications and the job a worker has. Changing occupation and sector of industry simultaneously has the smallest influence.

Just as in all the other models, all variables that might be a remedy for skills obsolescence were included in the initial estimation of the model. However, none of these six variables has a significant effect on the probability of a substantial decrease in the suitability of the qualifications and the job a worker has. This is not due to multicollinearity. Therefore, all remedy-variables were excluded from the analysis shown here. However, the occupational level, which was included as a correction variable, exerts a positive influence, implying that workers in the higher occupations are less likely to suffer from skills obsolescence by market developments or company-specific skills obsolescence. 
Table 6

Skills obsolescence (substantial worsening of suitability of qualifications for current job) by market developments or firm changes explained using a binomial logit model, standard errors in parentheses

Variable

coefficient

Risk factors: individual changes

Firm change

Firm and occupational change

Firm, occupational and sector of industry change

Other risk influencing factors

Occupational level in 1996

Constant

-2 log likelihood $=632.71$

$n=1408$
1.2927
1.0986
$1.4006(0.5207)^{\star *}$

${ }^{\star \star}=$ significant at a $5 \%$ level of significance

\section{Conclusions}

In this paper, the relation between risk factors and skills obsolescence and the role remedies can play to counter it, is dealt with. To accomplish this, an analysis that relates skills obsolescence, risk factors and remedies was carried out for each type of skills obsolescence. Risk factors are expected to increase the risk of skills obsolescence; remedies are expected to lower this risk. We here briefly restate the main findings of our analyses.

Wear is, as we expected, indeed related to work conditions. In addition, older workers have a higher risk of this type of skills obsolescence, while employees in higher occupations face lower risks. Remedies for skills obsolescence have no countering effects, which suggests that the preferred way to prevent skills obsolescence is improving working conditions.

Furthermore, the analyses show that the risk of job-specific skills obsolescence, just as is suggested in the literature, is significantly related to a number of developments that take place in society. Three of the four developments increase the probability of this type of skills obsolescence. These are technological, organisational and demographic developments. The willingness to participate in training courses decreases the probability of job-specific skills obsolescence. This implies that taking post-initial training courses is an important remedy for countering the effects of the different developments taking place in society.

Skills obsolescence due to market developments can manifest itself in two distinct ways. Firstly, some workers may loose their jobs and flow from employment to unemployment or non-participation, due to skills obsolescence by market developments. Secondly, other 
workers may suffer from skills obsolescence, but do not loose their current job. In this case, skills obsolescence is caused by changes in occupation, sector of industry or the firm. The risk of skills obsolescence by market developments measured by a higher outflow into unemployment or non-participation is positively related to the employment developments by type of educational background. In addition, having a flexible contract increases this risk. Two remedy-variables that were identified at the beginning of this article are important in countering skills obsolescence by market developments. It is worth noting that these remedies both measure willingness to take certain actions. The capacity to do so seems to be of less importance.

Finally, in the analysis where the risk of skills obsolescence by market developments or company-specific skills obsolescence is measured by a substantial decrease in the workers assessment of the suitability of the qualifications they have in their current job, three changes measured at the individual level are important. Of these three variables, changing occupation, sector of industry and firm simultaneously has the highest positive effect on the probability that there is a substantial decrease of the suitability of the qualifications and the job a worker has. Changing occupation and sector of industry simultaneously has the smallest influence. The variables that might be a remedy for skills obsolescence have no significant effect on the probability of a substantial decrease of the suitability of the qualifications and a worker's current job. From the analysis it becomes clear that the occupational level has a risk-decreasing effect.

In addition to the results that are obtained from the empirical parts of this paper, the analyses show that skills obsolescence is often very hard to measure using data-sources that are currently available. This has the practical implication that proxies have to be used quite often. Therefore, the development of datasources that focus on skills, risk factors and remedies for skills obsolescence simultaneously can be valuable in improving our understanding of the causes of and the cures for skills obsolescence.

\section{References}

Bélanger, P., \& R.M. Falgás (1997), Adult Education and Aging. Trends and Critical Issues. Adult Education and Development, 49, 161-164.

Bishop, J. (1997). Expertise and Excellence: Skill Development in the United States. In B. W. M. Hövels, W.J. Nijhof, A.M.L. Van Wieringen \& M. Van Dyck (Eds.), Beroepsonderwijs en Volwasseneneducatie Nader Bekeken (pp. 400), Den Haag: VUGA Uitgeverij.

Chelius, J.R. (1974), The Control of Industrial Accidents: Economic Theory and Empirical Evidence

(Reprint Series 551), Durham: Institute for Research in the Behavioural, Economic and Management Sciences.

De Grip, A. \& J. Hoevenberg (1996), Upgrading in the European Union (Research Memorandum ROA-RM-1996/3E), Maastricht: Researchcentrum voor Onderwijs en Arbeidsmarkt.

De Grip, A., J. Van Loo \& J. Sanders (1999), Employability in Action: An Industry Employability Index (Skope Research Paper No. 5 ), Oxford, UK: Skope. 
De Grip, A., M. Van Smoorenburg \& L. Borghans (1997), The Dutch Observatory on Employment and Training (ROA Working Paper W-1997/2E), Maastricht: Research Centre for Education and the Labour Market.

Green, F., D. Ashton, B. Burchell, B. Davies \& A. Felstead (1997), Are British Workers Getting More Skilled, Paper presented at the LOWER, London School of Economics.

Groot, W. (1998), Enterprise-related Training: A Survey (pp. 30), Amsterdam.

Hyatt, C. (1995), Lifetime Employability, How to Become Indispensable, New York: Mastermedia Limited.

Johnston, R. (1994), Jobs, Unemployment and Education for Work, Studies in Continuing Education, 16(1), pp. 37-51.

Maddala, G. S. (1983), Limited-Dependent and Qualitative Variables in Econometrics. Cambridge UK: Cambridge University Press.

McDowell, J.M. (1982), Obsolescence of Knowledge and Career Publication Profiles: Some Evidence of Differences among Fields in Costs of Interrupted Careers, The American Economic Review, 72 (4), pp. 752-768.

Neumann, S. \& A. Weiss (1995), On the Effects of Schooling Vintage on Experience-Earnings Profiles: Theory and Evidence. European Economic Review, 39, pp. 943-955.

OECD (1996), Measuring what People Know, Human Capital Accounting for the Knowledge Economy, Paris: OECD.

Pillay, H. (1998), Cognitive Skills Required in Contemporary Workplaces, Studies in Continuing Education, 20(1), pp. 71-81.

Rajan, A. (1996), Employability in the Finance Sector, Rhetoric vs Reality, Human Resource Management Journal, 7(1), pp. 67-78.

Thijssen, J.G.L. (1987), Het Leren van de Verouderende Werknemer in Veranderende Organisaties. Paper presented at the Concres Onderzoeks-Thema-Groep Onderwijsleerprocessen, Nijmegen.

Thijssen, J.G.L. (1997), Leren om te Overleven, over Personeelsontwikkeling als Permanente Educatie in een Veranderende Arbeidsmarkt, Bilthoven: Oratie.

Watkins, K.E. \& V.J. Marsick (1993), Sculpting the Learning Organization, Lessons in the Art and Science of Systemic Change, (First ed.), San Francisco: Jossey-Bass Publishers.

Wolff, E. (Forthcoming in 1999), Technology and the Demand for Skills: In A. De Grip \& L. Borghans (Eds.), The Overeducated Worker?, The Economics of Skills Utilization, Cheltenham, UK: Edward Elgar. 
